\title{
Airway Epithelial Cell Expression of Interleukin-6 in Transgenic Mice Uncoupling of Airway Inflammation and Bronchial Hyperreactivity
}

\author{
Bruno F. DiCosmo, ${ }^{\star \ddagger}$ Gregory P. Geba, * Dominic Picarella, ${ }^{\ddagger}$ Jack A. Elias, ${ }^{\star}$ John A. Rankin, "Barry R. Stripp, \\ Jeffrey A. Whitsett, ${ }^{1}$ and Richard A. Flavell's \\ * Pulmonary and Critical Care Section, Department of Internal Medicine, ${ }^{\ddagger}$ Department of Immunobiology, and ${ }^{\S}$ Howard Hughes \\ Medical Institute, Yale University School of Medicine, New Haven, Connecticut 06510; "West Haven Veterans Administration Medical \\ Center, West Haven, Connecticut 06516; and 'Children's Hospital Medical Center, Cincinnati, Ohio 45229
}

\begin{abstract}
We produced transgenic mice which overexpress human IL6 in the airway epithelial cells. Transgenic mice develop a mononuclear cell infiltrate adjacent to large and mid-sized airways. Immunohistochemistry reveals these cells to be predominantly $\mathrm{CD4}^{+}$cells, $\mathrm{MHC}$ class $\mathrm{II}^{+}$cells, and $\mathrm{B220}^{+}$ cells. Transgenic mice and nontransgenic mice had similar baseline respiratory system resistance $(0.47 \pm 0.06$ vs $0.43 \pm 0.04 \mathrm{cmH}_{2} \mathrm{O} / \mathrm{ml}$ per $\mathrm{s}$ at 9 wk of age, $P=\mathrm{NS}$ and $0.45 \pm 0.07$ vs $0.43 \pm 0.09 \mathrm{cmH}_{2} \mathrm{O} / \mathrm{ml}$ per s at 17 wk of age, $P$ $=$ NS). Transgenic mice, however, required a significantly higher log dose of methacholine to produce a $100 \%$ increase in respiratory system resistance as compared with nontransgenic littermates $(1.34 \pm 0.24$ vs $0.34 \pm 0.05 \mathrm{mg} / \mathrm{ml}, P$ $\leq 0.01$ ). We conclude that the expression of human IL-6 in the airways of transgenic mice results in a $\mathrm{CD4}^{+}, \mathrm{MHC}$ class $\mathrm{II}^{+}, \mathrm{B220}^{+}$lymphocytic infiltrate surrounding large and mid-sized airways that does not alter basal respiratory resistance, but does diminish airway reactivity to methacholine. These findings demonstrate an uncoupling of IL-6induced airway lymphocytic inflammation and airway hyperresponsiveness and suggest that some forms of airway inflammation may serve to restore altered airway physiology. (J. Clin. Invest. 1994. 94:2028-2035.) Key words: cytokines - airway physiology • lung biology - methacholine • airway hyperresponsiveness
\end{abstract}

\section{Introduction}

Asthma is a chronic disease characterized clinically by recurring episodes of bronchospasm, physiologically by airway hyperresponsiveness to a variety of stimuli, and pathologically by airway inflammation. Indirect evidence supports the hypothesis that the inflammatory response is responsible for the airway obstruction and airway hyperresponsiveness. For example, the number of eosinophils and activated $\mathrm{T}$ cells in asthmatic bronchial submucosa correlates with disease severity and degree of hyperresponsiveness (1-5). Although the mechanism by which airway inflammation causes reversible airway obstruction and hyperresponsiveness is unknown, it has been suggested that

Address correspondence to Richard A. Flavell, Ph.D., Chairman, Department of Immunobiology, Yale School of Medicine, 310 Cedar Street, 424 FMB, New Haven, CT 06510.

Received for publication 7 February 1994 and in revised form 21 June 1994

The Journal of Clinical Investigation, Inc

Volume 94, November 1994, 2028-2035 they are a consequence of the elaboration of various mediators and cytokines in the asthmatic airway (6-8).

In contrast to normals, the presence of various cytokines has been demonstrated in the bronchoalveolar lavage fluid (BALF) ${ }^{1}$ and/or biopsies of asthmatic airways. These include GM-CSF, TNF, interleukin (IL) -1, IL-2, IL-3, IL-4, IL-5, and IL-6 (912). In most reports, it is assumed that the dysregulated production of the cytokine being evaluated plays a role in the development of asthmatic manifestations. It is equally reasonable, however, to believe that the production of these cytokines may also represent a normal healing response in the damaged airway which is designed to normalize airway physiology. This quandary is well illustrated via an analysis of the in vitro effects of IL-6.

IL-6 has a variety of well documented proinflammatory effects that are potentially relevant to asthmatic inflammation, including its ability to stimulate the proliferation of thymocytes and mature T cells $(13,14)$, stimulate cytotoxic T lymphocyte differentiation (15), upregulate IL-4-dependent IgE production (16), and mediate the terminal differentiation and immunoglobulin production of B cells (13). In contrast, IL-6 has also been demonstrated to diminish tissue inflammation in animal models of hypersensitivity pneumonitis (17), oxygen toxicity (18), and endotoxin-induced lung injury (19), and to inhibit macrophage production of IL-1 and TNF in vitro (20).

To define the basic mechanisms by which inflammation alters airway hyperresponsiveness, we undertook studies designed to determine whether the inappropriate expression of one inflammatory cytokine in the airway would be sufficient to induce an inflammatory infiltrate and alter airway physiology. Since asthma is a chronic inflammatory disease, we took advantage of the distribution of the Clara cells in the airway (mouse conducting airways are 50-60\% Clara cells) (21) and used the Clara cell CC10 promoter to express the human IL-6 gene chronically in airway epithelial cells. In this study we address three questions with respect to the biologic activity of IL-6 in vivo: (a) whether the upregulated expression of IL-6 in the airway is sufficient to produce an inflammatory response; $(b)$ whether this leads to increased airway resistance; and (c) whether upregulated expression of IL- 6 in the airway alters bronchial reactivity. These studies demonstrate that IL- 6 can be expressed in high quantities in mouse lung using the $\mathrm{CC} 10$ promoter and that CC10-IL-6 transgenic mice develop a chronic peribronchial inflammatory response. Of importance, they also demonstrate that despite this inflammation CC10-IL6 transgenic mice are hyporesponsive to methacholine, illustrat-

1. Abbreviations ùsed in this paper: BALF, bronchoalveolar lavage fluid; MCh, methacholine; PC100, provocative challenge 100 . 


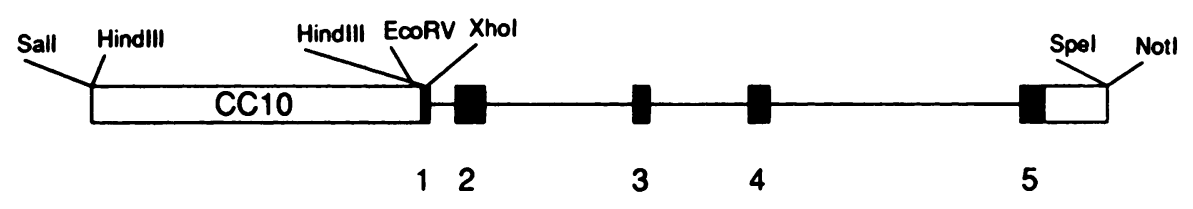

Figure 1. CC10-IL-6 transgene. The CC10 promoter was fused 5 ' of the translation start site in exon 1 of human genomic IL-6. The IL-6 gene contains five exons (solid boxes) and four introns (lines), the fifth exon contains a $3^{\prime}$ untranslated region (open box). Restriction sites used for cloning are shown. ing a remarkable dissociation of airway inflammation and airway reactivity.

\section{Methods}

Production of transgenic mice. The 5'-flanking region of the rat $\mathrm{CC} 10$ promoter was isolated and characterized as described previously (22). The CC10 promoter was isolated as a HindIII fragment and subcloned into the HindIII site in pKS-Bluescript. The locus encoding human IL6 was the generous gift of Dr. S. Akira and Dr. T. Kishimoto. The IL6 gene was isolated as a 4.8-kb Xhol (blunted with the Klenow fragment of DNA polymerase), SpeI fragment and subcloned into the EcoRV/ SpeI site in pKS-CC10. The CC10-IL-6 plasmid was extracted from bacterial suspension and purified through two sequential $\mathrm{CsCl}$ gradients (23). The purified DNA was digested with NotI and SalI to generate the CC10-IL-6 fragment (Fig. 1), separated by electrophoresis through $1 \%$ agarose gel (SeaKem GTG; FMC Corp. BioProducts, Rockland, $\mathrm{ME}$ ), and isolated by electroelution into dialysis tubing (23). The DNA fragment was purified through Elutip D columns by following the manufacturer's instructions (Schleicher and Schuell, Inc., Keene, NH) and dialyzed on filters against injection buffer $(0.01 \mathrm{M}$ Tris $\bullet \mathrm{HCl} / 0.1 \mathrm{mM}$ EDTA, pH 7.5). Transgenic mice were made in $(\mathrm{CBA} \times \mathrm{C} 57 \mathrm{BL} / 6)$ $F_{2}$ animals as described (24), and positive animals were identified by Southern blot analysis of tail DNA using a ${ }^{32} \mathrm{P}$-labeled 516-bp XhoI, XbaI IL-6 gene fragment as a probe (25).

IL-6 levels in BALF. BALF was obtained by inserting PE 50 tubing (Clay Adams, Parsippany, NJ) via a tracheotomy in pentobarbital (90 $\mathrm{mg} / \mathrm{kg}$ ) anesthetized mice and lavaging with three successive washes of $0.5 \mathrm{ml}$ of phosphate-buffered saline (PBS) with $0.1 \%$ bovine serum albumin (BSA). Each BALF aliquot was centrifuged, and the supernatants were harvested and stored individually at $-70^{\circ} \mathrm{C}$ until ready to use. All measurements were made on the first aliquot of BALF.

Measurements of IL-6 protein were made using an IL-6 ELISA kit following the manufacturer's instructions (Quantikine; R\&D Systems, Inc., Minneapolis, MN). This ELISA has been shown to have no significant cross-reactivity with other cytokines and no cross-reactivity with mouse IL-6 at levels of $100 \mathrm{ng} / \mathrm{ml}$ (R\&D Systems, Inc., product insert).

Measurements of IL-6 activity were made using B9.11 cells. B9.11 cells in $\log$ phase of growth were incubated with $100 \mu \mathrm{l}$ of BALF in triplicate for $72 \mathrm{~h}$ in 96 -well microtiter plates in a humidified $37^{\circ} \mathrm{C}, 5 \%$ $\mathrm{CO}_{2}$ incubator. $\left[{ }^{3} \mathrm{H}\right]$ Thymidine was added, and plates were incubated at $37^{\circ} \mathrm{C}$ for an additional $4 \mathrm{~h}$. Cells were harvested, and $\left[{ }^{3} \mathrm{H}\right]$ thymidine incorporation was counted by liquid scintillation.

Histologic sections. Lungs were inflated with $10 \%$ formalin, removed en block, placed in Tissue Tek III cassettes (Miles Inc., West Haven, CT) and placed overnight in $10 \%$ formalin. Paraffin embedding, tissue sectioning, slide mounting, hematoxylin and eosin staining, elastin staining, and trichrome staining were performed as a service by the Department of Pathology, Yale University School of Medicine.

Immunohistochemistry on frozen sections. Lungs were inflated with $1 \times$ PBS/33\% (vol/vol) OCT Tissue-Tek compound (Miles Inc.) and snap frozen in OCT by submersion into 2-methylbutane (Aldrich Chemical Co., Milwaukee, WI) cooled with dry ice. Tissue sections were cut, transferred onto silane-treated glass slides, fixed in $4 \%$ acetone for 15 min, and stained with various antibody reagents as described previously (26). Sections were blocked with avidin-biotin blocking kit (Vector Labs, Inc., Burlingame, CA) and BSA before reaction with biotinylated primary antibody. The slides were then washed three times in $0.1 \mathrm{M}$

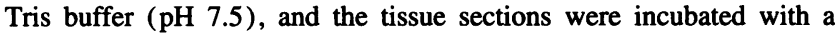
prediluted streptavidin-alkaline phosphatase solution (Kirkegaard \& Perry Laboratory, Gaithersburg, MD) for $1 \mathrm{~h}$. The sections were washed and developed using Fast Red staining system (Sigma Immunochemicals, St. Louis, MO) in accordance with manufacturer's instructions. The slides were counterstained in Meyer's hematoxylin and then mounted with Aquamount histologic mounting medium (Lerner Laboratories, Pittsburgh, PA).

Areas of cellular infiltration were photographed. Infiltrates were divided into quadrants, and cells were counted. Positively staining cells with each antibody were counted and expressed as a percentage of the total number of cells in the infiltrate.

Physiologic assessment. Mice were anesthetized with pentobarbital $(90 \mathrm{mg} / \mathrm{kg})$ and tracheostomized with an 18-gauge angiocatheter (Baxter Scientific, McGraw Park, IL). Airway resistance in mice was measured using a modification of the techniques described by Martin et al. (27). With these techniques, changes in the lung volume of anesthetized and tracheostomized mice were measured plethysmographically by determining pressure in a Plexiglas chamber using an in line Microswitch pressure transducer. Flow was measured by differentiation of the volume signal, and transpulmonary pressure was determined by a second Microswitch pressure transducer placed in line with the plethysmograph and an animal ventilator. Resistance was then calculated using the method of Amdur and Mead (28). Resistance of the tracheostomy catheter was eliminated, and baseline measurements of pulmonary resistance were obtained by ventilating the mouse in the plethysmograph at volumes of $0.4 \mathrm{ml}$ at a rate of 150 breaths/min previously shown to produce normal arterial blood gases (27). Each mouse was studied at baseline. Bronchial hyperreactivity was then determined by methacholine (MCh) challenge as described previously (29). Increasing concentrations of MCh in PBS were administered by nebulization (201-ml breaths), and the pulmonary resistance was calculated precisely $1 \mathrm{~min}$ later. Stepwise increases in MCh dose were then given until the pulmonary resistance, in comparison with baseline level, had at least doubled. The data were expressed as the provocative challenge $100(\mathrm{PC100})$, the dose at which pulmonary resistance was $100 \%$ above baseline level.

Statistical analysis. Values were expressed as means \pm SE. The data were normally distributed, and group means were compared with Student's two-tailed, unpaired $t$ test with StatView software for Macintosh.

\section{Results}

Production of transgenic mice. We wished to test the hypothesis that IL-6 directly mediates local inflammation in vivo and that an inflammatory response localized to the airway is sufficient to result in altered susceptibility to $\mathrm{MCh}$-induced bronchoconstriction. We constructed several lines of transgenic mice in which expression of the human IL-6 gene was regulated by the CC10 promoter. This promoter has been successfully used previously to direct the expression of chloramphenicol acetyltransferase in the conducting airways of the lung (22). Of 35 progeny screened by Southern blot analysis of tail DNA, 6 were positive for the transgene with copy numbers ranging from 5 to 50 per genome (data not shown). Founders 9 (10 copies), 11 (20 copies), and 17 (50 copies) were bred with C57BL/6 mice. 
Table I. IL-6 Levels in BALF and Serum

\begin{tabular}{cccc}
\hline Sample & Transgene + & Transgene - & $P$ value \\
\hline & $n g / m l$ & $n g / m l$ & \\
BALF & $10.1 \pm 3.6$ & $<0.003$ & $\leq 0.025$ \\
Serum & $0.243 \pm 0.010$ & $<0.003$ & $\leq 0.0005$
\end{tabular}

The levels of human IL-6 in BALF and serum of transgene-positive $(+)$ and -negative ( -$)$ mice were assessed by ELISA as described. IL6 values represent mean \pm SEM, $n=2-3$ samples per group.

The CC10-IL-6 transgene is translated into IL-6 in the airway. To determine if the CC10-IL-6 transgene is appropriately expressed in these animals, BAL was performed on transgene-positive and transgene-negative littermates of progeny of founder 9 and 17, and human IL-6 protein levels were assayed by ELISA. Human IL-6 was found only in the transgene-positive animals of each line, at similar levels (Table I, data from line 9 only). Transgenic animals had a mean of $10.1 \pm 3.6 \mathrm{ng} / \mathrm{ml}$ of BALF IL-6 while nontransgenic animals had no $(<0.003 \mathrm{ng} / \mathrm{ml})$ detectable human IL-6 ( $P \leq 0.025)$. The levels of serum IL-6 were also assayed. Significant IL-6 could be detected in the serum of the transgenic but not in the serum of the nontransgenic animals (Table I), $243 \pm 10 \mathrm{pg} / \mathrm{ml}$ versus nondetectable $(<3.13 \mathrm{pg} / \mathrm{ml})(P \leq 0.0005)$. In all cases, the levels of serum IL-6 were significantly lower than the levels of BALF IL-6.

To determine if the IL- 6 was biologically active, B9.11 cells were incubated with BALF from transgene-positive and -negative littermates. B9.11 cells had significantly more proliferation when incubated with BALF from transgene-positive animals than when incubated with BALF from transgene-negative littermates as demonstrated by $\left[{ }^{3} \mathrm{H}\right]$ thymidine incorporation, 30 $\times 10^{3}$ counts per minute $(\mathrm{cpm})$ vs $1 \times 10^{3} \mathrm{cpm}, P \leq 0.0005$ (Fig. 2).

Expression of IL-6 in the airway results in airway inflammation. The expression of IL-6 in the airway was sufficient to induce an overwhelming infiltration of mononuclear cells that was consistently seen in areas adjacent to large and mid-sized airways in transgenic progeny from lines 9,11 , and 17 but not in transgene-negative littermates (Fig. 3). The epithelium in the transgenic animals appeared normal. No eosinophils were seen in the infiltrate, nor was there any subepithelial fibrosis by trichrome or elastin staining (data not shown). All other organs were examined histologically and appeared normal (data not shown).

The airway infiltrating cell population consists of $\mathrm{CD}^{+}$, $\mathrm{CD}^{+}, \mathrm{CD} 8^{+}, \mathrm{MHC}$ class $\mathrm{II}^{+}$, and $\mathrm{B220}^{+}$cells. The results obtained with these IL- 6 transgenic mice suggested that expression of IL-6 in the airway was sufficient to initiate an inflammatory response. The phenotype of the infiltrating cells was therefore analyzed by immunohistochemistry of frozen lung sections. These data reveal that the predominant cell type is an MHC class $\mathrm{II}^{+}, \mathrm{B}_{220}{ }^{+}$cell with the remainder being $\mathrm{CD}^{+}, \mathrm{CD}^{+}$ cells. Few $\mathrm{CD} 8{ }^{+}$cells and no $\mathrm{F} 4 / 80^{+}$cells were noted (Fig. 4). Areas of infiltrate were divided into quadrants, and cells were counted. $\mathrm{CD}^{+}$cells make up $25 \%$ of the cells in the infiltrate, of which $90 \%$ are $\mathrm{CD}^{+}$and $10 \%$ are $\mathrm{CD} 8^{+} . \mathrm{B}^{2} 20^{+}$ cells make up $75 \%$ of the cells in the infiltrate. None of the antibodies reacted with sections of lung from transgene-negative

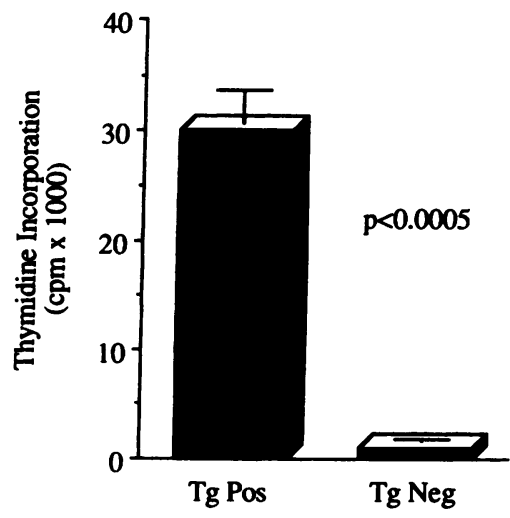

Figure 2. IL-6 activity. B9.11 cells were incubated with BALF from transgene-positive ( $\mathrm{Tg}$ $P o s)$ and transgene-negative $(\mathrm{Tg} \mathrm{Neg})$ mice. Cell proliferation was measured as $\left[{ }^{3} \mathrm{H}\right]$ thymidine incorporation in counts per minute. Cells incubated with BALF from $\mathrm{Tg}$ Pos mice had significantly more proliferation than cells incubated with BALF from $\mathrm{Tg}$ Neg mice $\left(30 \times 10^{3}\right.$ vs $\left.1 \times 10^{3} \mathrm{cpm}\right)(P \leq 0.0005)$. Each assay was done in triplicate on BALF of individual mice. BALF was obtained from four $\mathrm{Tg}$ Pos and four $\mathrm{Tg}$ Neg mice. The bars represent the means \pm SEM.

mice because there was no airway infiltration in these animals (data not shown).

Expression of IL-6 results in stunted growth. The expression of IL-6 in the airway caused transgenic mice to be stunted in growth compared with the transgene-negative animals. As seen in Fig. 5, transgenic mice are of equal weight to their littermate negatives when they are young, but as they age the littermate negatives have a steeper growth curve. At 16 wk of age, transgenic males weigh $26.2 \pm 0.78 \mathrm{~g}$ while nontransgenic males weigh $30.8 \pm 1.3 \mathrm{~g}(P \leq 0.025)$. The difference in transgenic and nontransgenic females was even more marked and could be seen as early as $11 \mathrm{wk}$ of age, $19.8 \pm 0.67$ vs $21.7 \pm 0.6 \mathrm{~g}$ $(P \leq 0.05)$ and $21.38 \pm 0.78$ vs $23.68 \pm 0.67 \mathrm{~g}(P \leq 0.01)$, respectively. No difference was found in males at 9 and $11 \mathrm{wk}$ or in females at $9 \mathrm{wk}$.

IL-6 expression and airway inflammation does not increase basal airway resistance. To determine whether the infiltrating lymphocytes affected airway resistance, we measured the resistance of the respiratory system in the transgene-positive mice and compared them with age-matched transgene-negative littermate mice. The results show that $\mathrm{IL}-6$ transgenic mice have no difference in respiratory resistance despite having massive airway inflammation (Table II), $0.47 \pm 0.06$ vs $0.43 \pm 0.04 \mathrm{~cm}$ $\mathrm{H}_{2} \mathrm{O} / \mathrm{ml}$ per s $(P=\mathrm{NS})$ at $9 \mathrm{wk}$ and $0.45 \pm 0.07$ vs $0.43 \pm 0.09$ $\mathrm{cm} \mathrm{H}_{2} \mathrm{O} / \mathrm{ml}$ per s $(P=\mathrm{NS})$ at $17 \mathrm{wk}$ for transgenic and nontransgenic animals, respectively. We concluded that, despite having massive airway inflammation, there is no change in baseline pulmonary resistance.

IL-6-expressing transgenic mice are less reactive to methacholine. To assess the degree of hyperresponsiveness in IL-6 transgenic mice, $\mathrm{MCh}$ challenge was performed. The results show that IL-6 transgenic mice require a significantly higher $\log$ dose of MCh to achieve a $100 \%$ increase (PC100) in the respiratory resistance, $1.14 \pm 0.25$ vs $0.63 \pm 0.12(P \leq 0.05)$ for females and $1.34 \pm 0.24$ vs $0.34 \pm 0.05(P \leq 0.01)$ for males in two separate experiments (Fig. 6). We concluded that IL-6 overexpression decreases $\mathrm{MCh}$-induced bronchoconstriction in these animals.

\section{Discussion}

We studied the in vivo role of IL-6 in airway inflammation, airway obstruction, and reactivity to methacholine. Our goal in 

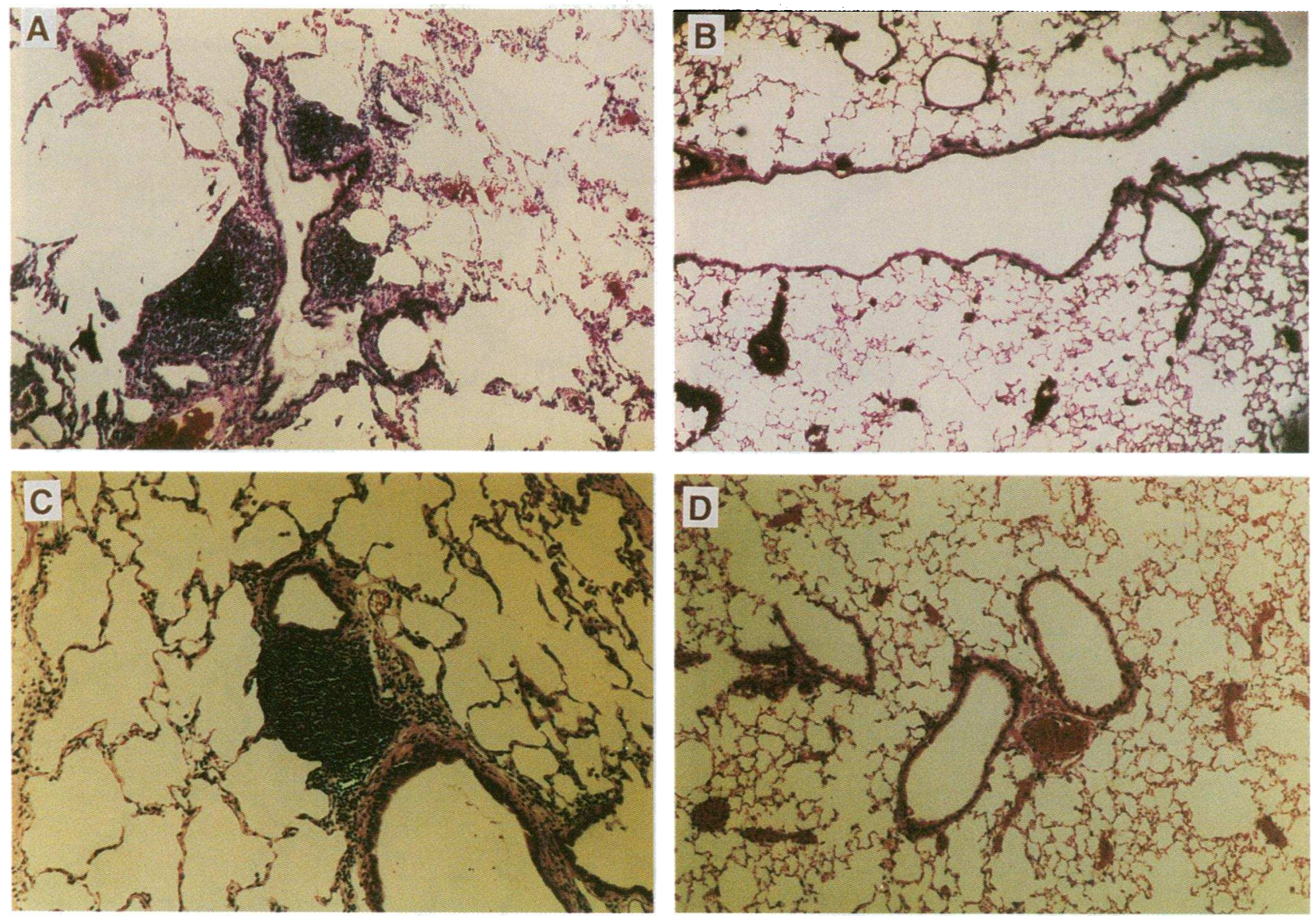

Figure 3. Lung histology. Lungs were inflated and fixed in $10 \%$ formalin overnight. Sections were embedded in paraffin, cut onto slides, and stained with hematoxylin and eosin. Large airways are shown in the top panels. $(A)$ Transgene positive, $\times 4 ;(B)$ transgene negative, $\times 4$. Mid-sized airways are shown in the bottom panels. $(C)$ Transgene positive, $\times 10 ;(D)$ transgene negative, $\times 10$.

these studies was twofold: first, to determine whether IL-6 causes an inflammatory response, and, second, to determine whether this inflammation is sufficient to produce airway obstruction or airway hyperresponsiveness. Our hypothesis was that the inappropriate expression of $I L-6$ in the airway would be a sufficient signal to initiate and sustain an inflammatory response and that this inflammation would cause airway hyperresponsiveness. To provide a constant supply of cytokine in the microenvironment of the airway while limiting the complex systemic effects of this cytokine, we produced transgenic mice in which the IL-6 gene was expressed in airway epithelial cells under the direction of the Clara cell $\mathrm{CC} 10$ promoter. Our results show that IL-6 expression in airway epithelial cells was sufficient to induce a lymphocytic inflammatory response around large and mid-sized airways (Fig. 3). Importantly, our results disproved the second half of our hypothesis since this inflammation did not alter basal airway resistance (Table II) and diminished the methacholine sensitivity of these animals (Fig. 6).

IL-6 is a pleotropic cytokine that is the product of a single gene on chromosome 7 . It is produced by a wide variety of cells including fibroblasts, monocyte/macrophages, endothelial cells, T and B lymphocytes, and keratinocytes. Studies from this and other laboratories have shown that IL-6 is induced by a number of cytokines (IL-1, TNF, PDGF), viruses, and endotoxin via transcriptional and posttranscriptional mecha- nisms (for review see reference 30 ). IL-6 possesses an impressively diverse spectrum of biologic activities, both proinflammatory and antiinflammatory. The proinflammatory effects include the ability to stimulate the proliferation of thymocytes and mature $T$ cells $(13,14)$, stimulate cytotoxic $T$ lymphocyte differentiation (15), upregulate $\mathrm{IL}-4-$ dependent IgE synthesis (16), mediate the terminal differentiation of $B$ cells, and induce synthesis of IgM, IgG, and IgA by B cells (31). The antiinflammatory properties of IL-6 include the induction of the hepatic acute phase response (32), stimulation of the proliferation of keratinocytes (33), inhibition of macrophage and monocyte TNF production $(20,34)$, inhibition of macrophage proliferation (35), and reduction of monocyte cytotoxicity (34). Not surprisingly, IL- 6 has been implicated in the pathogenesis of a variety of inflammatory, infectious, and malignant disorders including wound healing (36), acute transplant rejection (37), diabetes mellitus (38), rheumatoid arthritis (39), Castleman's disease (40), cardiac myxomas (41), mesangioproliferative glomerulonephritis (42), myeloblastic leukemia (43), Kaposi's sarcoma (44), and asthma (45-48). In the majority of these disorders, however, only an association between abnormal and/ or dysregulated IL-6 production and disease expression has been documented. In some, IL-6 might have directly contributed to disease pathogenesis. In others, it is felt that IL-6 elaboration is a nonspecific generalized alarm signal which limits tissue injury via the induction of the hepatic acute phase response and 

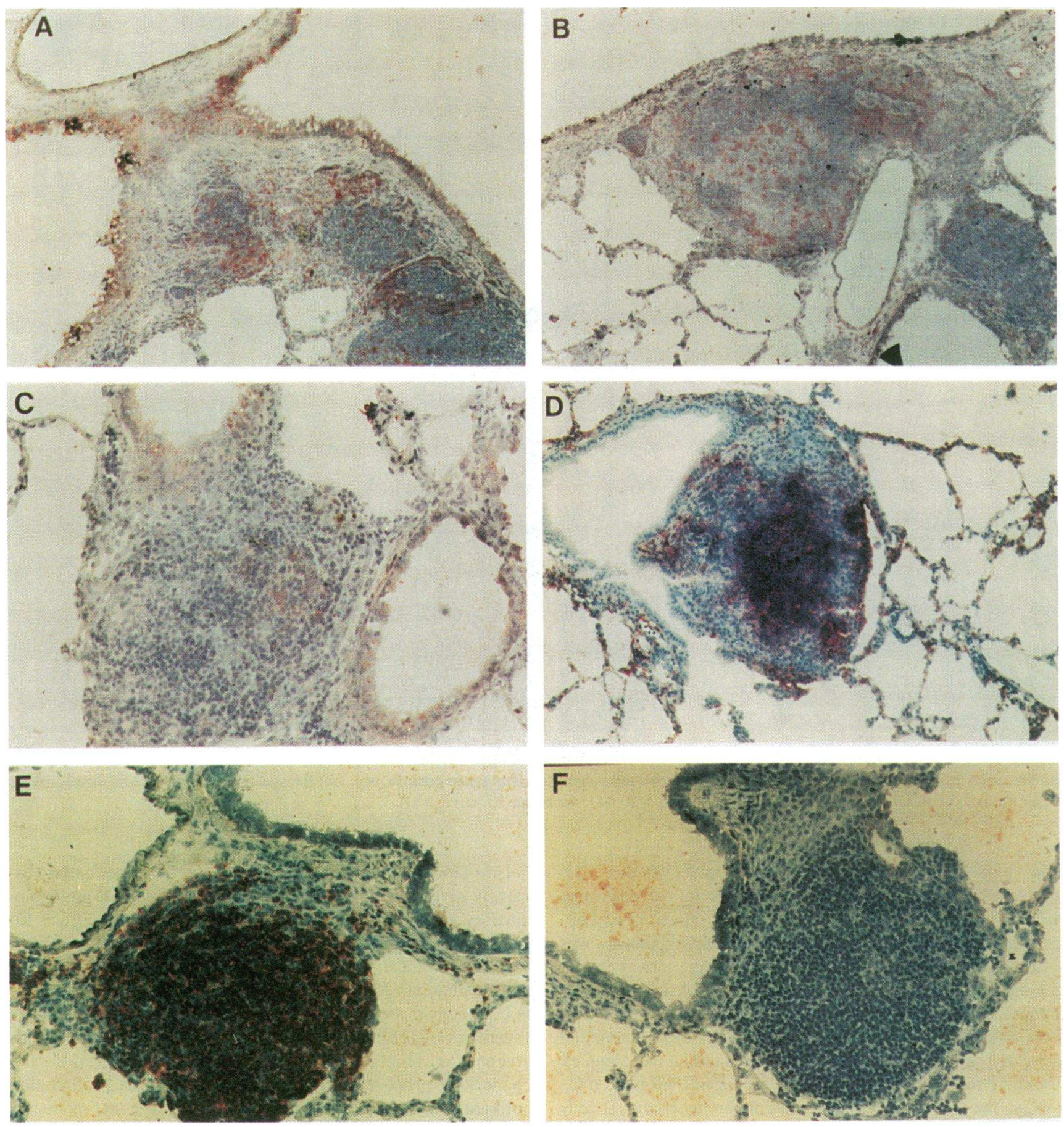

Figure 4. Immunohistochemistry. Lungs were fixed in acetone and frozen at $-70^{\circ} \mathrm{C}$, cut onto silane-coated slides, stained with appropriate $1^{\circ}$ biotinylated antibodies, incubated with streptavidin-alkaline phosphatase, and developed using Fast Red, counterstained with hematoxylin. All sections shown are from transgene-positive animals. $(A)$ Anti-CD3, $\times 10 ;(B)$ anti-CD4, $\times 10 ;(C)$ anti-CD8, $\times 20 ;(D)$ anti-MHC class II, $\times 10$; $(E)$ anti-B220, $\times 20$; and $(F)$ anti-F4/80, $\times 20$.

other poorly clarified mechanisms. This is clearly the case in animal models of hypersensitivity pneumonitis where treatment with IL-6 decreases pulmonary inflammation and scarring while treatment with an anti-IL-6 antibody increases pulmonary inflammation and scarring (17), in animal models of oxygen toxicity where IL-6 enhances TNF and IL-1 -induced protection against oxygen toxicity (18), and in animal models of pulmonary inflammation where intratracheal IL-6 inhibits the acute neutrophilic lung infiltration that occurs after the administration of intratracheal endotoxin (19).

A variety of studies have demonstrated dysregulated IL6 production in situations relevant to the asthmatic diathesis. Elevated levels of IL-6 have been found in the BALF of patients with asthma $(45,46)$. Immunocytochemical evaluation of BAL cells from these asthmatics demonstrates that IL-6 is predominantly produced by nonciliated epithelial cells (Clara cells) and 


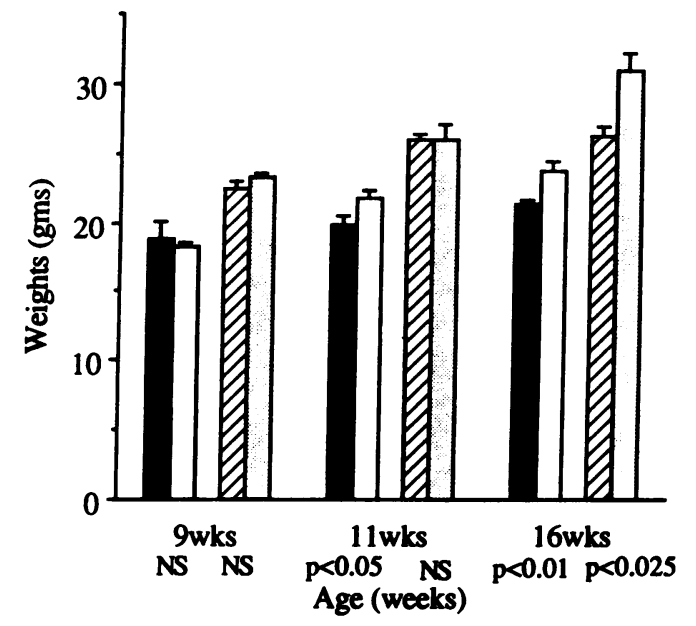

Figure 5. Body weights. Transgene-positive males ( $\mathrm{Tg}$ Pos $M$, striped bars) weighed significantly less than transgene-negative males ( $\mathrm{Tg} \mathrm{Neg}$ $M$, dotted bars) at 16 wk of age, $26.2 \pm 0.78$ vs $30.8 \pm 1.3 \mathrm{~g}, P \leq 0.025$. Transgene-positive females ( $\mathrm{Tg}$ Pos F, filled bars) also weighed significantly less than transgene-negative females ( $\mathrm{Tg} \mathrm{Neg} \mathrm{F}$, open bars) at 11 and $16 \mathrm{wk}, 19.8 \pm 0.67$ vs $21.7 \pm 0.6 \mathrm{~g}, P \leq 0.05$ and $21.38 \pm 0.78$ vs $23.68 \pm 0.67 \mathrm{~g}, P \leq 0.01$, respectively. There was no difference in the males at 9 or $11 \mathrm{wk}$ or in the females at $9 \mathrm{wk}$. Each data point represents the mean of two to six mice \pm SEM.

alveolar macrophages (45). Bronchial epithelial cells obtained by bronchial biopsy of asthmatic patients and placed in culture produce elevated levels of IL-6 (47). Alveolar macrophages obtained after bronchial allergen challenge of asthmatic patients secrete elevated levels of IL-6 (48). Similarly, an asthmagenic stimulus, ozone, induces elevated levels of IL-6 in the BALF of normal human subjects (49). The role that IL-6 plays in these asthma states, however, has not been determined. Our studies suggest that IL-6 in these disorders may actually serve to normalize airway physiology.

Studies of the inflammatory response in asthmatic airways have demonstrated that $\mathrm{T}$ lymphocytes, particularly $\mathrm{Th}_{2}$-type cells (9) and eosinophils (1-7), appear to play an important role in this process. Using monoclonal antibodies, we have demonstrated that the peribronchial infiltrate in IL-6 transgenic mice consists predominantly of $\mathrm{MHC}$ class $\mathrm{II}^{+}, \mathrm{B} 220^{+}$cells (B cells), and CD4 ${ }^{+}$cells ( $\mathrm{T}$ cells) (Fig. 4). Despite this impressive inflammatory response, however, these animals do not have altered basal airway resistance (Table II) and have a significantly higher log PC100 (Fig. 6), thus are less responsive to methacholine than their transgene-negative littermates.

The difference in physiology produced by IL-6-induced

Table II. Airway Resistance

\begin{tabular}{rccc}
\hline Age & Transgene + & Transgene - & $P$ value \\
\hline$w k$ & $c m H_{2} O / m l$ per $s$ & $c m H_{2} O / m l$ per $s$ & \\
9 & $0.47 \pm 0.06$ & $0.43 \pm 0.04$ & NS \\
17 & $0.45 \pm 0.07$ & $0.43 \pm 0.09$ & NS
\end{tabular}

Airway resistance was measured in transgene-positive $(+)$ and -negative $(-)$ mice as described. Resistance values represent mean \pm SEM, and there were three to seven mice per group.

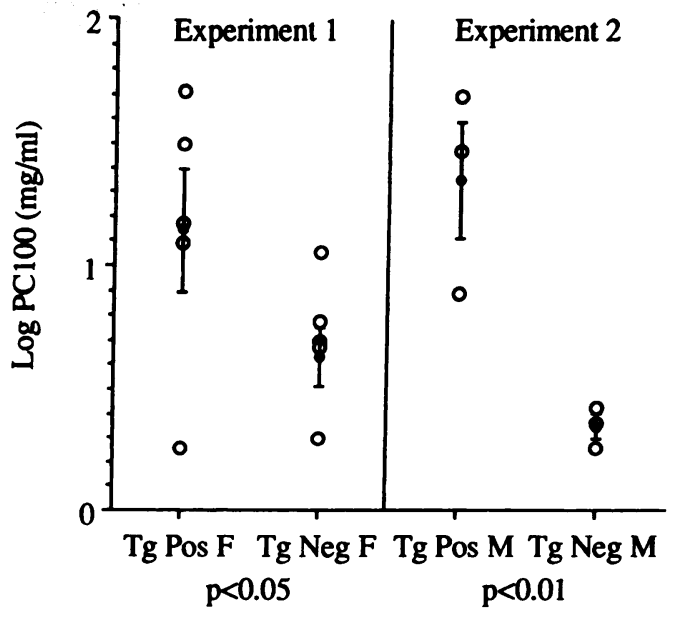

Figure 6. Airway hyperresponsiveness. Two separate experiments were done comparing age-matched transgene-positive and transgene-negative mice. Transgene-positive females ( $T g P o s F)$ had a significantly higher $\log \mathrm{PC} 100$ than transgene-negative females $(\mathrm{Tg} \mathrm{Neg} F)(1.15$ vs 0.6$)$ $(P \leq 0.05)$; transgene-positive males ( $T g P o s M)$ had a significantly higher $\log$ PC100 than transgene-negative males $(\mathrm{Tg} \mathrm{Neg} \mathrm{M})$ (1.35 vs $0.3)(P \leq 0.01)$, thus, transgene-positive mice are less responsive to methacholine than transgene-negative mice. Each open point represents one mouse, and the solid point represents the mean of the group \pm SEM.

airway inflammation and that associated with airway inflammation in asthma is striking. This may be the result of differences in the subset, state of activation, or location of cells that are infiltrating the airways in these two processes. Alternatively, eosinophilic infiltration and/or subepithelial fibrosis may be crucial to the development of asthmatic airway hyperreactivity since these features are commonly seen in asthmatics $(50,51)$ and are lacking in our IL- 6 transgene-positive animals.

Three transgenic models have been constructed previously with IL-6. We have used the rat insulin promoter to stimulate the selective expression of IL- 6 in the pancreas of NOD ( spontaneously diabetic) mice. These animals have delayed onset of diabetes compared with their littermate control NOD mice, thus suggesting protection (our unpublished data). Suematsu et al. (52) used the IgG heavy chain promoter to overexpress IL-6 systemically. These mice developed a polyclonal hyperglobulinemia and a diffuse plasmacytosis. In contrast, Turksen et al. (53) used the keratin promoter to express IL-6 in the epidermis. In this location, IL-6 did not produce psoriasis and did not cause inflammatory cell infiltration. Instead, there was thickening of the stratum corneum suggesting that, in this model, IL-6 production served as a protective mechanism against infection or injury (53). These results illustrate the importance of analyzing the effects of IL-6 in an organ-specific fashion and support our use of an airway-selective promoter to analyze the role of IL-6 in the asthmatic diathesis.

The relationship between airway inflammation and hyperresponsiveness remains poorly defined. In the model described in this manuscript, we can unambiguously implicate the product of a single well defined gene (IL-6) in airway inflammation. More importantly, we show for the first time in an animal model an uncoupling of airway inflammation and airway hyperresponsiveness. This finding leads us to hypothesize that some forms of airway inflammation may not necessarily lead to changes in basal airway muscle tone, airway edema, or hyperreactivity 
typical of the asthmatic diathesis. Our findings suggest that IL6 promotes a type of airway inflammation that decreases airway hyperresponsiveness to bronchoconstrictor agents. Thus, although IL-6 may contribute to airway inflammation, it is unlikely to be the only cytokine responsible for the establishment and maintenance of all aspects of the asthmatic diathesis. IL-6 production in asthmatic airways may in fact represent an attempt to mount a healing response designed to restore normal airway responsiveness in airways that are inflamed and hyperresponsive as a result of other insults and/or mediators. The demonstration that IL-6-induced airway inflammation can diminish airway responsiveness has important implications for the pathogenesis and treatment of the asthmatic diathesis.

\section{Acknowledgments}

We thank Antonella Tarallo and Deborah Hayden for their technical assistance and Cindy Hughes and Debbie Butkus for producing the transgenic mice used in these experiments. We also would like to thank Prabir Ray for his assistance in preparing the manuscript.

R. A. Flavell is an Investigator of the Howard Hughes Medical Institute. B. F. DiCosmo is supported by the American College of Chest Physicians.

\section{References}

1. Corrigan, C. J., and A. B. Kay. 1992. T cells and eosinophils in the pathogenesis of asthma. Immunol. Today. 13:501-507.

2. Holgate, S. T., W. R. Roche, and M. K. Church. 1991. The role of the eosinophil in asthma. Am. Rev. Respir. Dis. 143:S66-S70.

3. DeMonchy, J. G. R., H. F. Kauffman, and P. Venge. 1985. Bronchoalveolar eosinophilia during allergen-induced late asthmatic reactions. Am. Rev. Respir. Dis. 131:373-376.

4. Corrigan, C. J., A. Hartnell, and A. B. Kay. 1988. T lymphocyte activation in acute severe asthma. Lancet. i:1129-1131.

5. Corrigan, C. J., and A. B. Kay. 1990. CD4 T lymphocyte activation in acute severe asthma. Am. Rev. Respir. Dis. 141:970-977.

6. Metzger, W. J., G. W. Hunninghake, and H. B. Richerson. 1985. Late asthmatic responses: inquiry into mechanisms and significance. Clin. Rev. Allergy. 3:145-165.

7. Bradley, B. L., M. Azzawi, M. Jacobson, B. Assoufi, J. V. Collins, A. A.-M. Irani, L. B. Schwartz, S. R. Durham, P. K. Jeffery, and A. B. Kay. 1991. Eosinophils, T-lymphocytes, mast cells, neutrophils and macrophages in bronchial biopsy specimens from atopic subjects with asthma: comparison with atopic subjects without asthma and normal control subjects and relationship to bronchial hyperresponsiveness. J. Allergy Clin. Immunol. 88:661-674.

8. Johnston, S. L., and S. T. Holgate. 1990 . Cellular and chemical mediators: their roles in allergic diseases. Curr. Opin. Immunol. 2:513-524.

9. Robinson, D. S., Q. Hamid, S. Ying, A. Tsicopoulos, J. Barkans, A. Bentley, C. Corrigan, S. R. Durham, and A. B. Kay. 1992. Predominant $\mathrm{T}_{\mathrm{H}_{2}-\text { like bronchoal- }}$ veolar T-lymphocyte population in atopic asthma. N. Engl. J. Med. 326:298-304.

10. Kay, A. B., S. Ying, V. Varney, M. Gaga, S. R. Durham, R. Moqbel, A. J. Wardlaw, and Q. Hamid. 1991. Messenger RNA expression of the cytokine gene cluster, interleukin 3 (IL-3), IL-4, IL-5, and granulocyte/macrophage colony-stimulating factor in allergen-induced late-phase cutaneous reactions in atopic subjects. J. Exp. Med. 173:775-778.

11. Durham, R. S., S. Ying, V. Varney, M. R. Jacobson, R. M. Sudderick, I. S. Mackay, A. B. Kay, and Q. A. Hamid. 1992. Cytokine mRNA expression for IL-3, IL-4 and IL-5 and granulocyte macrophage colony stimulating factor in the nasal mucosa after local allergen provocation: relationship to tissue eosinophilia. J. Immunol. 148:2390-2394.

12. Desreumaux, P., A. Janin, J. F. Colombel, L. Prin, J. Plumas, D. Emilie, G. Torpier, A. Capron, and M. Capron. 1992. Interleukin 5 messenger RNA expression by eosinophils in the intestinal mucosa of patients with coeliac disease. J. Exp. Med. 175:293-296.

13. Elias, J., G. Trinchieri, J. Bech, P. Simon, P. Sehgal, L. May, and J. Kern. 1989. Synergistic interaction of IL-6 and IL-1 mediated the thymocyte stimulating activity produced by recombinant IL-1 stimulated fibroblasts. J. Immunol. 142:509-514.

14. Uyttenhove, C., P. G. Coulie, and J. Van Snick. 1988. T cell growth and differentiation induced by interleukin-HP1/IL-6, the murine hybridoma/plasmacytoma growth factor. J. Exp. Med. 167:1417-1427.

15. Okada, S., T. Suda, J. Suda, N. Tokuyama, K. Nagayoshi, Y. Miura, and
H. Nakauchi. 1991. Effect of interleukin-3, interleukin-6 and granulocyte colonystimulating factor on sorted murine splenic progenitor cells. Exp. Hematol. (NY). 19:42-46.

16. Vercelli, D., H. Jabara, K. Arai, T. Yokota, and R. S. Geha. 1989. Endogenous IL-6 plays an obligatory role in IL-4 dependent IgE synthesis. Eur. J. Immunol. 19:1419-1424.

17. Denis, M. 1992. Interleukin-6 in mouse hypersensitivity pneumonitis: changes in lung free cells following depletion of endogenous IL-6 or direct administration of IL-6. J. Leukocyte Biol. 52:197-201.

18. Tsan, M., J. White, P. DelVechio, and J. B. Shaffer. 1992. IL-6 enhances TNF $\alpha$ and IL- 1 induced increase of Mn superoxide dismutase mRNA and $\mathrm{O}_{2}$ tolerance. Am. J. Physiol. 263:L22-L26.

19. Ulrich, T., S. Yin, K. Guo, S. Y. Eunhee, D. Remick, and J. Castillo. 1991. Intratracheal injection of endotoxin and cytokines. Am. J. Pathol. 138:10971101.

20. Schindler, R., J. Mancilla, S. Endres, R. Ghorbani, S. C. Clark, and C. A. Dinarello. 1990. Correlation and interaction in the production of IL-6, IL-1 and TNF in human blood mono-nuclear cells: IL-6 suppresses IL-1 and TNF. Blood. 75:40-47.

21. Pack, R. J., L. H. Al-Ugaily, and G. Morris. 1981. The cells of the tracheobronchial epithelium of the mouse: a quantitative light and electron microscope study. J. Anat. 132:71-84.

22. Stripp, B. R., P. L. Sawaya, D. S. Luse, K. A. Wikenheiser, S. E. Wert, J. A. Huffman, D. L. Lattier, G. Singh, S. L. Katyal, and J. A. Whitsett. 1992 cis-acting elements that confer lung epithelial cell expression of the $\mathrm{CC}_{10}$ gene J. Biol. Chem. 267:14703-14712.

23. Sambrook, J., E. F. Fritsch, and T. Maniatis. 1989. Molecular Cloning: A Laboratory Manual. Cold Spring Harbor Laboratory, Cold Spring Harbor, NY. 120-124.

24. Hogan, B., F. Constantini, and E. Lacy. 1986. Manipulating the Mouse Embryo: A Laboratory Manual. Cold Spring Harbor Laboratory, Cold Spring Harbor, NY. 46-48.

25. Li, C.-b., P. W. Gray, P.-F. Lin, K. M. Mcgrath, F. H. Ruddle, and N. H. Ruddle. 1987. Cloning and expression of murine lymphotoxin cDNA. J. Immunol. 138:4496-4501.

26. DeCamilli, P., R. Cameron, and P. Greengard. 1983. Synopsin 1, a nerve terminal-specific phosphoprotein. Its general distribution in synapses of the central and peripheral nervous system demonstrated by immunofluorescence in frozen and plastic sections. J. Cell Biol. 96:1337-1354.

27. Martin, T., N. Gerard, S. Galli, and J. Drazen. 1988. Pulmonary responses to bronchoconstrictor agonists in the mouse. J. Appl. Physiol. 64:2318-2323.

28. Amdur, M. O., and J. Mead. 1958. Mechanics of respiration in unanesthetized guinea pigs. Am. J. Physiol. 192:364-368.

29. Geba, G. P., C. D. Wegner, W. W. Wolyniec, and P. W. Askenase. 1992. In vivo airway hyperreactivity in mice can be produced by cell mediated bronchial inflammation. Am. Rev. Respir. Dis. 145:A36. (Abstr.)

30. Zitnik, R., and J. Elias. 1992. Interleukin-6 and the lung. In Cytokines of the Lung. J. Kelly, editor. Marcel Dekker, Inc., New York. 229-280.

31. Muraguchi, A., T. Hirano, B. Tang, T. Matsuda, Y. Horii, K. Nakajima, and T. Kishimoto. 1988. The essential role of B cell stimulatory factor 2 (BSF2/IL-6) for the terminal differentiation of B cells. J. Exp. Med. 167:332-344.

32. Sehgal, P. 1990. Interleukin-6: a regulator of plasma protein gene expression in hepatic and non hepatic tissues. Mol. Biol. \& Med. 7:117-130.

33. Luger, T., T. Schwarz, J. Krutman, R. Kirnbauer, P. Neuner, A. Kock, A. Urganski, W. Borth, and E. Schauer. 1989. Interleukin-6 is produced by epidermal cells and plays an important role in the activation of human $\mathrm{T}$ lymphocytes and natural killer cells. Ann. NY Acad. Sci. 557:454-464.

34. Aderkan, D., L. E. Junming, and J. Vilcek. 1989. IL-6 inhibits lipopolysaccharide induced tumor necrosis factor production in cultured human monocytes, U937 cells and in mice. J. Immunol. 143:3517-3523.

35. Reidy, M., and C. Stewart. 1992. Inhibitory role of interleukin-6 in macrophage proliferation. J. Leukocyte Biol. 52:125-127.

36. Nishimoto, N., K. Yoshizaki, H. Tagoh, M. Monden, S. Kishimoto, T. Hirano, and T. Kishimoto. 1989. Elevation of serum IL-6 prior to acute phase proteins in the inflammation of surgical operation. Clin. Immunol. Immunopathol. 50:399-401.

37. Yoshimura, N., T. Oka, and B. D. Kahan. 1991. Sequential determination of serum IL-6 levels as an immunodiagnostic tool to differentiate rejection from nephrotoxicity in renal allograft recipients. Transplantation (Baltimore). 51:172176.

38. Campbell, I. L., A. Cutri, A. Wilson, and L. C. Harrison. 1989. Evidence for interleukin- 6 production by and effects on the pancreatic beta cells. J. Immunol. 143:1188-1191.

39. Swaak, A. J., A. Van Roogen, E. Nieuwenhuis, and L. A. Aarden. 1988. IL-6 in synovial fluid and serum of patients with rheumatic disease. Scand. $J$. Immunol. 17:469-474.

40. Yoshizaki, K., T. Matsuda, N. Nishimoto, T. Kuritani, L. Taeho, K. Aosaza, T. Nakahata, H. Kawai, H. Yagoh, T. Komori, et al. 1989. Pathogenic significance of IL-6 in Castleman's disease. Blood. 74:1360-1367.

41. Jourdan, M., R. Bataille, J. Seguin, X. G. Xhang, P. A. Chaptal, and B. 
Klein. 1990. Constitutive production of IL-6 and immunologic features in cardiac myxomas. Arthritis Rheum. 33:398-402.

42. Horii, Y., A. Muraguchi, M. Iwanno, T. Matsuda, T. Hirayama, H. Yamada, Y. Fujii, K. Dohi, H. Ishikawa, Y. Ohmoto, et al. 1989. Involvement of IL-6 in mesangial proliferative glomerulonephritis. J. Immunol. 143:3949-3955.

43. Hoang, T., A. Haman, O. Goncalves, G. G. Wong, and S. C. Clark. 1988 IL-6 enhances growth factor dependent proliferation of the blast cells of acute myeloblastic leukemia. Blood. 72:823-826.

44. Miles, S. A., A. R. Rezai, J. F. Salazar-Gonzalez, M. Vander Mayen, R. Stevens, D. M. Logan, R. T. Mitsuyasu, T. Taga, T. Hirano, T. Kishimoto, and O. Martinez-Maza. 1990. AIDS kaposi sarcoma derived cells produce and respond to IL-6. Proc. Natl. Acad. Sci. USA. 87:4068-4072.

45. Mattoli, S., V. L. Mattoso, M. Saloperto, L. Allegra, and A. Fasoli. 1991. Cellular and biochemical characteristics of bronchoalveolar lavage fluid in symptomatic and nonallergic asthma. J. Allergy Clin. Immunol. 87:794-802.

46. Broide, D. H., M. Lotz, A. J. Cuomo, D. A. Coburn, E. C. Federman, and S. I. Wasserman. 1992. Cytokines in symptomatic asthma airways. J. Allergy Clin. Immunol. 89:958-967.

47. Marini, M., E. Vittori, J. Hollemborg, and S. Mattoli. 1992. Expression of the potent inflammatory cytokines, granulocyte-macrophage-colony-stimulating factor and interleukin-6 and interleukin-8, in bronchial epithelial cells of patients with asthma. J. Allergy Clin. Immunol. 89:1001-1009.

48. Gosset, P., A. Tsicopoulos, B. Wallaert, C. Vannimenus, M. Joseph, A. Tonnel, and A. Capron. 1991. Increased secretion of tumor necrosis factor $\alpha$ and interleukin- 6 by alveolar macrophages consecutive to the development of the late asthmatic reaction. J. Allergy Clin. Immunol. 88:561-571.

49. Devlin, R. B., W. F. McDonnell, R. Mann, S. Becker, D. E. House, D. Schreinemachers, and H. L. Koren. 1991. Exposure of humans to ambient levels of ozone for 6.6 hours causes cellular and biochemical changes in the lung. Am. J. Respir. Cell Mol. Biol. 4:72-81.

50. Dunnill, M. S. 1960. The pathology of asthma with special reference to changes in the bronchial mucosa. J. Clin. Pathol. 13:27-33.

51. Gleich, G. J. 1990. The eosinophil and bronchial asthma: current understanding. J. Allergy Clin. Immunol. 85:422-436.

52. Suematsu, C. T., K. Matsuda, N. Aozasa, N. Akira, S. Nakoano, J.-I. Ohno, K.-I. Miyazaki, T. Yamamura, T. Hirano, and T. Kishimoto. 1989. IgG plasmacytosis in IL-6 transgenic mice. Proc. Natl. Acad. Sci. USA. 86:75477551.

53. Turksen, K., T. Kupper, L. Degenstein, I. Williams, and E. Fuchs. 1992. Interleukin-6: insight to its function in skin by overexpression in transgenic mice. Proc. Natl. Acad. Sci. USA. 89:5068-5072. 